\title{
A Study on Derivational Affixes of Indonesian Noun-Formation in Newspaper Editorial: A Semantic Perspective
}

\author{
Zainuddin ${ }^{1}$ \\ ${ }^{1}$ English and Literature Department, Faculty of Languages and Arts, Universitas Negeri Medan, Indonesia \\ Correspondence: Zainuddin, English and Literature Department, Faculty of Languages and Arts, Universitas \\ Negeri Medan, Indonesia. Tel: 62-813-6140-9598. E-mail: zainuddin.gayo52@yahoo.com
}

Received: March 30, 2016

Accepted: April 20, 2016 Online Published: May 25, 2016

doi:10.5539/ijel.v6n3p148

URL: http://dx.doi.org/10.5539/ijel.v6n3p148

\begin{abstract}
This study aimed at investigating the types of derivational affixes of Indonesian noun-formation in newspaper editorial of kompas. Kompas newspaper is wide circulation or it has a tremendous reading circulation in Indonesia. This study used a descriptive qualitative method by using the theory of structural linguistics to interprete the grammatical meaning carried out in the process of derivational affixes of Indonesian noun-formation. The method of analysis data applied distributional method in terms of classifyng lexical category of Indonesian derived nouns producing affixation. The theory referring to the patterns of derivation and structure, which was developed by Aronoff \& Fudeman (2005). The object of the study is a derivational affixes of Indonesian noun-formation that exist in newspaper editorial of Indonesian kompas. Based on the analysis of the data the findings showing that there are 7 types of derivational affixes of Indonesian noun-formation exists in the newspaper editorial (tajuk rencana) of kompas namely (1) suffix -an, (2) infix -em- + suffix -an, (3) infix -el-, (4) confix per-an, (5) confix ke-an, (6) confix pe-an and (7) confix pen-an. These types are considered important viewed from the morphology study in the field of linguistics. This is to say that the phenomena referring to the point of the function of the language is considered.
\end{abstract}

Keywords: derivational affixes, indonesian noun-formation, in newspaper editorial

\section{Introduction}

\subsection{Overview on Indonesian Language}

Indonesian is the medium of instruction in educational institutions at all levels throughout the country. In the early years of the Republic, local languages continued to be used in some places as the medium of instruction in the first years of primary school but this practice has now almost entirely disappeared. In schools and universities most textbooks are in Indonesian, but at the tertiary level, especially in highly specialised coures and at the advanced level of study, textbooks in English are also widely used (Quinn, 2001). From this point of view Indonesian language functions as the important medium in education in terms of formal and informal instruction. Quinn also stated that the way Indonesian is used by high-ranking officials and in government documents also provides models imitated throughout the country. The print media and television too are key sources of models. Indeed the nation's "serious" newspapers and magazines like, for example, the dailies Kompas and Republika, and the weekly newsmagazines Tempo and Gatra have made a point of creating new terms and cultivating innovation in formal style. Indonesian is the official as well as the national language of the Republic of Indonesia spoken by more than 160 million people over the country. As the official language Indonesian functions as a means of communication in which lagislative, executive, and judicial affairs are administered (Zainuddin, 1986).

\subsection{Derivational Affix (Morpheme)}

Derivational affix is a part of the study of morphology in the field of linguistics. The morphology which studies derivational morphemes and the principles governing the new words is called derivational morphology (Sibarani, 2002, p. 47). Bauer (1988, p. 76) stated that derivational affixes may caused a change in category, but that inflectional ones never do, we need a closer definition of category. If we define category at the coarse level of noun, verb, adjective, then the criterion isolates some derivational affixes. It is clear that Bauer differenciated the concept of derivational affix and inflectional affix in terms of changing the category. Derivational affix change the category as well as the effect to the meaning, while inflectional affix never change the category or the 
inflectional structure is never change the meaning. In relation to the meaning Haspelmath (2002, p. 68) said that derivational meanings are much more diverse than inflectional categories. Besides cross-linguistically widespread meanings such as agent noun (e.g., drink $k_{\mathrm{V}} \rightarrow$ drink-er ${ }_{N}$ ), quality noun (e.g., kind $d_{\mathrm{A}} \rightarrow$ kind-ness $s_{N}$ ) and facilitative adjective (e.g., read $\rightarrow$ $\rightarrow$ read-able $\mathrm{A}_{\mathrm{A}}$ ), we also find highly specific meaning that are confined to a few languages. In this matter Haspelmath enphesized that derivational meanings concerning much more affect to the categories change compared to the inflectional one. According to Haspelmath $(2002$, p. 68) derivational patterns commonly change the word-class of the base lexeme-i.e., nouns can be derived from verbs, adjectives from nouns, and so on. The following linguists Aronoff \& Fudeman (2005, p. 45) said that (1) derivation generally results in a change in lexical meaning or the lexical category of a particular word, while inflection does not, and (2) the application or non-application of inflectional morphology generally depends on the syntatic context (e.g., examples of words + derivational affixes Nouns to nouns (New York + ese, fish +ery, auto + biography, vice + president). According to Katamba (1993, p. 48) sometimes the presence of a derivational affix causes a major grammatical change, involving moving the base from one word-class into another as in the case of -ment (suffix), and word-class of input base govern $(\mathrm{V})$ and word-class of output word is noun $(\mathrm{N})$ example: govern-ment. Meaning result or product of doing the action indicated by the verb. In this case Katamba tends to emphesize the derivational affix on the use of the terms of input base (verb) out and word-class of output word becomes government.

In Indonesian, affixes take an important role and it so sensitive because the slightly affixes may cause so far different on meaning. There are four types of affixes, namely prefixes (awalan), suffixes (akhiran), circumfixes (apitan), and infixes (sisipan). These affixes are categorised into noun affixes, verb affixes and adjective affixes. Root words are either nouns or verbs, which can be affixed to derive new words, e.g., masak (to cook) yields memasak (cooks), memasakkan (cooks for), dimasak (cooked) as well as pemasak (a cook), masakan (a meal, cookery). Many initial consonants undergo mutation when prefixes are added: e.g., sapu (sweep) becomes penyapu (broom), panggil (to call) becomes memanggil (calls/calling), tapis (to sieve) becomes menapis (sieves).

Other examples of the use of affixes to change the meaning of a word can be seen with the word ajar (teach):

$$
\begin{aligned}
& \text { - } \quad \text { Ajar }=\text { teach } \\
& \text { - } \quad \text { Ajaran = teaching } \\
& \text { - } \quad \text { Belajar }=\text { to learn } \\
& \text { - Mengajar }=\text { to teach } \\
& \text { - } \quad \text { Diajar = being taught (intransitive) } \\
& \text { - } \quad \text { Diajarkan = being taught (transitive) } \\
& \text { - } \quad \text { Mempelajari = to study } \\
& \text { - } \quad \text { Dipelajari }=\text { being studied } \\
& \text { - } \quad \text { Pelajar }=\text { student } \\
& \text { - } \quad \text { Pengajar }=\text { teacher } \\
& \text { - Pelajaran }=\text { subject, education } \\
& \text { - } \quad \text { Pengajaran }=\text { lesson, moral of story } \\
& \text { - Pembelajaran = learning } \\
& \text { - } \quad \text { Terajar }=\text { taught (accidentally) } \\
& \text { - Terpelajar = well-educated, literally "been taught" } \\
& \text { - Berpelajaran = is educated, literally "has education" }
\end{aligned}
$$

(http://en.wikipedia.org).

In relation to the derivational affixes referring to the noun-formation, based on the information presented above the Indonesian affixes encompassing four types of affixes that can be concidered to form the noun-formation namely prefixes (awalan), suffixes (akhiran), circumfixes (apitan), and infixes (sisipan). By giving some example in term of derivational noun formation using the verb ajar (teach) is formulated in the case of using the prefix pe- (peN-) refers to the nasal sounds change such as pengajaran and pembelajaran as derived noun forming from circumfixes ( $p e N-a n)$. From the above examples it is said that suffix (pe-and -an) takes as the dominant one to form the noun formation. 
Chaer (2008) in his book entitled Morfologi Bahasa Indonesia, describing some affixes which are considered potential for derivational noun-formation in Indonesian language (Bahasa Indonesia). Such as the following types of affixes, prefix ke-, confix ke-an, prefix pe-, confix pe-an, confix per-an, suffix -an, suffix -nya, prefix ter-, and infix -el, -em dan, -er and also some other suffixes which are derived from foreign language.

In other book written by Kridalaksana (1982) entitled Pembentukan Kata dalam Bahasa Indonesia, exploring more typical numbers of affixes for derivational noun formation those are (suffix -an occurs 15 types, prefix keoccurs 3 types, prefix pe- occurs 9 types, prefix per- occurs 5 types, prefix se- occurs, confix ke-an occurs 6 types, confix pe-an occurs 2 types, confix per-an occurs 7 types and infix -el occurs 4 types, infix -er occurs 2 types). Both linguists, Chaer \& Kridalaksana gave us more information in searching the Indonesian word-formation, especially for noun-formation through the issue of affixation (afiksasi pembentukan nomina) in the study of morphology.

\section{Theoretical Background}

Allan (2001, p. 9) stated that the principal function of the theory is to explain data (words, sentences) from natural language. The goal of the theory is to explain all the data that it was constructed to explain; therefore, limitations on its range need to be clearly stated. A theory should have predictive power insofar as it raises expectations about data that have not yet come to light. It is absolutely necessary that a theory be internally consistent. Based on the principal function of the theory stated above, this research deals with the two different theories to be applied, namely 1) the theory of analysis data, and 2) the semantics theory. Describe in the following ways:

\subsection{Theory Analysis Data}

The theory of analysing data applied Scalise's Model (1984, p. 139) "Word Formation Rules" and "Derivation and Structure" model develoved by Aronoff \& Fudeman (1988, p. 117). The aplication of the two models are concidered relevant to analyse the data for Derivational Affixes of Indonesian Noun-Formation in Newspaper Editorial. The application of the Scalise's Model presented interms of word formation rule for noun formation (eg. -ia $(\mathrm{A} \rightarrow \mathrm{N})$ cortesia "kindness" (from cortese "kind"). The following presented Aronoff \& Fudeman model of Derivation and Structure, in terms of forming noun-formation take the English word reinterpretations ([[re$[\text { interpret }]_{\mathrm{v}}$-ation $]_{\mathrm{N}}$ ) "the act of reinterpreting". From the above example it can be explain that $r e$ - is the act of interpreting, a verb interpret form a new verb via the prefix re-and finally form a noun by adding the suffix -ation. The model is bracketing structure. The stucture of the morphologically complex words is made most clear when we use tree diagrams, like the following:

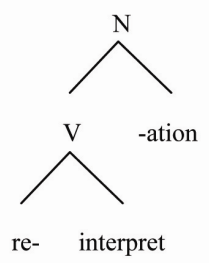

The diagram clearly shows that re- and the verb interpret form a unit, a verb, which attaches to the noun-forming -ation. In order to draw a tree diagram, it is first necessary to break a word down into its components and to fully understand how they fit together (Aronoff \& Fudeman, 1988, p. 118).

\subsection{Semantic Theory}

The language of semantic theory deals with the metalanguage. According to Allan (2001, p. 8) the language which a linguist uses to describe and analyse the object language is called the metalanguage. The basic requirement for metalanguage is to satisfactorily communicate the meaning of item-that is, any expression in the object language, whether it is a word, a phrase, or a sentence - in terms of an expression in the metalanguage. In analysing the meaning of words in the case of derivational affixes of Indonesian noun-formation the researcher applied the theory developed by Kridalaksana (1996, p. 23) and Chaer (2008, p. 29), both linguists concerning with the process of morphology in grammatical meaning of words formation in terms of affixation. In other words, grammatical meaning is the meaning appears in the morphological process as the effect of attaching any affix to the base form, for examples infixing -el- informing noun-formation in Indonesian language tunjuk (V) "pointing out" telunjuk (N) "index finger". In case the process of infixing suffix -el- to the verb tunjuk grammatically change the meaning as become derived noun telunjuk. Viewed from Nida's version, for examples suffix -er added to verb in such construction as worker, dancer, runner, andwalker. In the case suffix -er affects 
the meaning "the doer of the action" (also called "agentive") (Nida, 1993, p. 7). According to Nida this principle used the phrase "common semantic distinctiveness".

\section{Methodology}

This research applied descriptive and qualitative design. Descriptive method is aimed at investigating the process of derivational affixes of Indonesian noun-formationin newspaper editorial. In other words, this research concerning the analysis of Indonesian derivational affixes informing noun through newspaper editorial of Indonesian Kompas.

\section{The Object of the Study}

The object of the study is the derivational affixes of Indonesian noun-formation as found in the newspaper editorial (tajuk rencana) within the kompas. The reason for choosing daily newspaper editorial kompas is that, it is wide circulation or a very tremendous reading circulation compared with any other newspaper editorial as well as local newspaper editorial ones.

\section{Source of the Data}

Source of the data adopted from 8 sample of daily newspaper editorial of Indonesian kompas. The 8th sample of kompas is considered representative for this research, since they are taken in different week publication, namely stating from the firstweek, untill week the 8th within the length of more than 2 months.

\section{Procedure of Collecting Data}

The procedure of collecting data used documentary technique in terms of inventory method. The procedures are as the following stages:

(1) Reading every newspaper editorial

(2) Identifying the subject matter (derivational affixes)

(3) Classifying the subject matter as found in the newspaper editorial (the types of derivational noun formation)

(4) Interpreting the meaning of the process derivational affixes of Indonesian noun-formation

(5) Inventorying the data in terms of percentage

\section{Analysing Data}

In analysing the data income passing two different models as developed namely derivation and structure (DS) and word formation rule (WFR).

In order to be able to analyse the data, the researcher used contributed distribution in terms of types of derivational affixes of Indonesian noun-formation as the following:

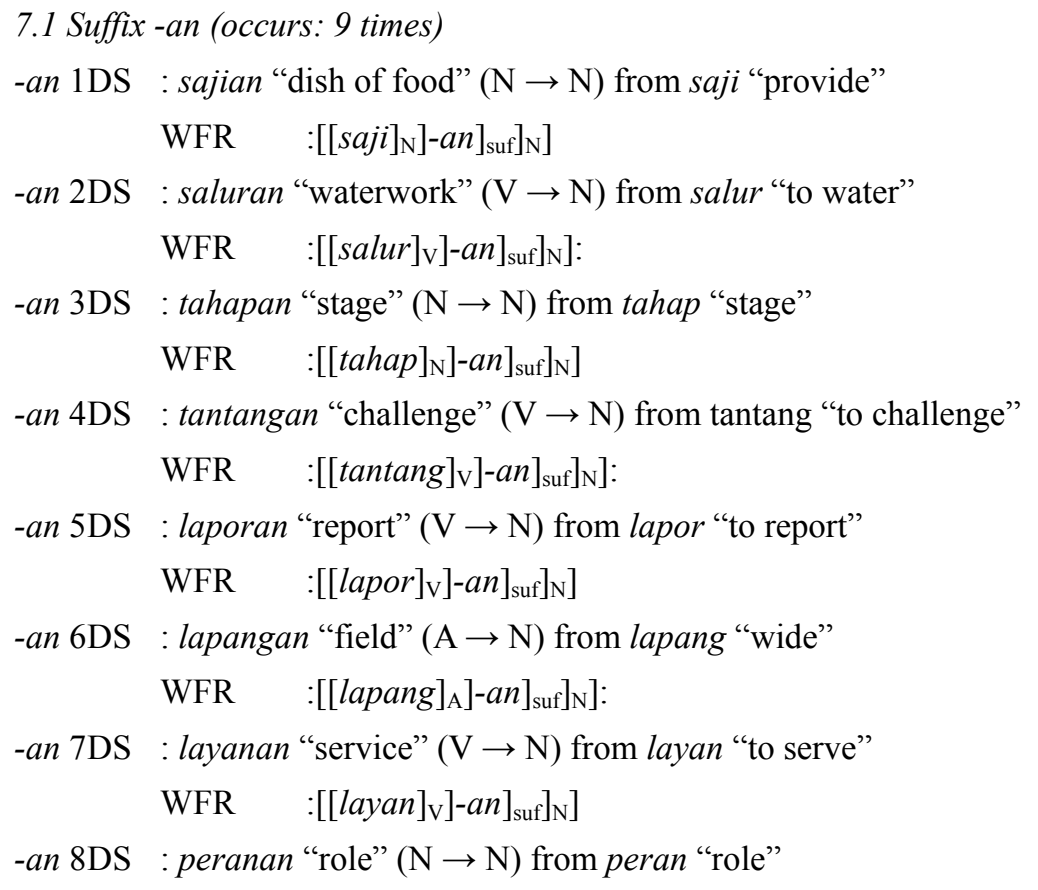


WFR :[[peran $\left.\left.\left.\left.]_{\mathrm{N}}\right]-a n\right]_{\text {suf }}\right]_{\mathrm{N}}\right]:$

-an 9DS : bangunan "building" $(\mathrm{V} \rightarrow \mathrm{N})$ from bangun "to build"

WFR :[[bangun $\left.\left.\left.\left.]_{\mathrm{V}}\right]-a n\right]_{\text {suf }}\right]_{\mathrm{N}}\right]$

7.2 Infix -em- + Suffix -an (occurs: 2 times)

$-e m-+-a n 1$ DS : pemilihan "process" $(\mathrm{V} \rightarrow \mathrm{N})$ from pilih "to choose"

WFR :[p[-em- $\left.\left.\left.\left.]_{\text {inf }}[\text { ilih }]_{\mathrm{V}}\right]-a n\right]_{\text {suf }}\right]_{\mathrm{N}}\right]$

-em- + -an 2 DS : pemanasan "process" $(\mathrm{V} \rightarrow \mathrm{N})$ from panas "making hot"

WFR :[p[-em- $\left.\left.\left.\left.]_{\text {inf }}[\text { anas }]_{\mathrm{V}}\right]-a n\right]_{\text {suf }}\right]_{\mathrm{N}}\right]$

7.3 Infix -el- (occurs: once)

-el-1 DS : pelaku "agent" $(\mathrm{A} \rightarrow \mathrm{N})$ from laku "behaviour"

WFR :[p[-el- $\left.\left.\left.]_{\text {inf }}[1 \mathrm{aku}]_{\mathrm{A}}\right]_{\mathrm{suf}}\right]_{\mathrm{N}}\right]$

7.4 Confix per-an (occurs: 10 times)

per-an 1 DS : perbedaan "opinion" $(\mathrm{N} \rightarrow \mathrm{N})$ from beda "difference"

WFR :[[per- $\left.\left.\left.\left.]_{\text {pre }}[\text { beda }]_{\mathrm{N}}\right]-\mathrm{an}\right]_{\text {suf }}\right]_{\mathrm{N}}\right]$

per-an 2 DS :persoalan "matter" $(\mathrm{N} \rightarrow \mathrm{N})$ from soal "question"

WFR :[[per- $\left.]_{\text {pre }}[\text { soal }]_{\mathrm{N}}\right]-$ an $\left.\left.]_{\text {suf }}\right]_{\mathrm{N}}\right]$

per-an 3 DS : perdebatan "subject of debate" $(\mathrm{N} \rightarrow \mathrm{N})$ from debat "debate"

WFR :[[per- $\left.\left.\left.\left.]_{\text {pre }}[\text { debat }]_{\mathrm{N}}\right]-\mathrm{an}\right]_{\mathrm{suf}}\right]_{\mathrm{N}}\right]$

per-an 4 DS : pernyataan "declaration" $(\mathrm{A} \rightarrow \mathrm{N})$ from nyata "real"

WFR :[[per- $\left.\left.\left.\left.]_{\text {pre }}[\text { nyata }]_{\mathrm{A}}\right]-\mathrm{an}\right]_{\mathrm{suf}}\right]_{\mathrm{N}}\right]$

per-an 5 DS : pertengahan "middle" $(\mathrm{N} \rightarrow \mathrm{N})$ from tengah "middle"

WFR :[[per- $\left.\left.\left.\left.]_{\text {pre }}[\text { tengah }]_{\mathrm{N}}\right]-\mathrm{an}\right]_{\mathrm{suf}}\right]_{\mathrm{N}}\right]$

per-an 6 DS : permasalahan "set of probem" $(\mathrm{N} \rightarrow \mathrm{N})$ from masalah "problem"

WFR :[[per- $\left.\left.\left.\left.]_{\text {pre }}[\text { masalah }]_{\mathrm{N}}\right]-\mathrm{an}\right]_{\mathrm{suf}}\right]_{\mathrm{N}}\right]$

per-an 7 DS : pernapasan "breathing" $(\mathrm{N} \rightarrow \mathrm{N})$ from nafas "breath"

WFR :[[per- $\left.]_{\text {pre }}[\text { nafas }]_{\mathrm{N}}\right]-$ an $\left.\left.]_{\text {suf }}\right]_{\mathrm{N}}\right]$

per-an 8 DS : pertanian "agriculture" $(\mathrm{N} \rightarrow \mathrm{N})$ from tani "farmer"

WFR :[[per- $\left.]_{\text {pre }}[\operatorname{tani}]_{\mathrm{N}}\right]-$ an $\left.\left.]_{\text {suf }}\right]_{\mathrm{N}}\right]$

per-an 9 DS : pertanahan "land affairs" $(\mathrm{N} \rightarrow \mathrm{N})$ from tanah "land"

WFR :[[per- $\left.\left.\left.\left.]_{\text {pre }}[\operatorname{tanah}]_{\mathrm{N}}\right]-\mathrm{an}\right]_{\text {suf }}\right]_{\mathrm{N}}\right]$

per-an $10 \mathrm{DS}$ : perkebunan "plantation" $(\mathrm{N} \rightarrow \mathrm{N})$ from kebun "garden"

WFR :[[per- $\left.\left.\left.\left.]_{\text {pre }}[\text { kebun }]_{\mathrm{N}}\right]-\mathrm{an}\right]_{\text {suf }}\right]_{\mathrm{N}}\right]$

7.5 Confix ke-an (occurs: 22 times)

ke-an 1 DS : kesempatan "oppurtunity" $(\mathrm{V} \rightarrow \mathrm{N})$ from sempat "time"

WFR :[[ke- $\left.\left.\left.\left.]_{\text {pre }}[\text { sempat }]_{\mathrm{V}}\right]-\mathrm{an}\right]_{\text {suf }}\right]_{\mathrm{N}}\right]$

ke-an 2 DS : kejadian "incident" $(\mathrm{V} \rightarrow \mathrm{N})$ from jadi "become"

WFR :[[ke- $\left.]_{\text {pre }}[\text { jadi }]_{\mathrm{V}}\right]$-an $\left.\left.]_{\text {suf }}\right]_{\mathrm{N}}\right]$

ke-an 3 DS : kepentingan "needs" $(\mathrm{A} \rightarrow \mathrm{N})$ from penting "importance"

WFR :[[ke- $\left.]_{\text {pre }}[\text { penting }]_{\mathrm{A}}\right]$-an $\left.\left.]_{\text {suf }}\right]_{\mathrm{N}}\right]$

ke-an 4 DS : kebijakan "wisdom" $(\mathrm{A} \rightarrow \mathrm{N})$ from bijak "wise"

WFR :[[ke- $\left.\left.\left.\left.]_{\text {pre }}[\text { bijak }]_{\mathrm{A}}\right]-\mathrm{an}\right]_{\mathrm{suf}}\right]_{\mathrm{N}}\right]$

ke-an 5 DS : kesungguhan "seriousness" $(\mathrm{A} \rightarrow \mathrm{N})$ from sungguh "actually" 


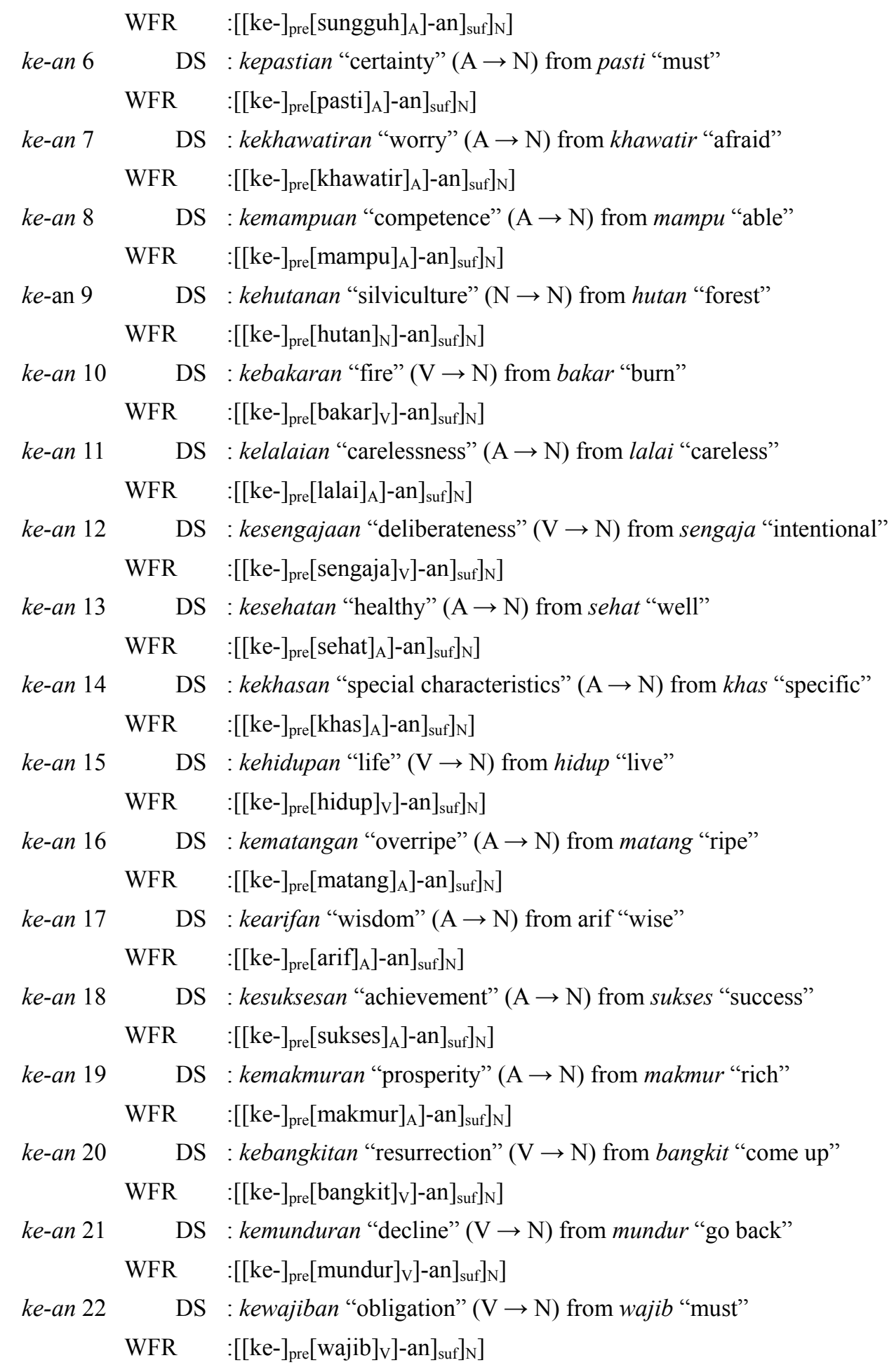

7.6 Confix pe-an (occurs: once)

pe-an 1 DS : penanganan "process" $(\mathrm{N} \rightarrow \mathrm{N})$ from tangan "hand"

WFR :[[pe- $\left.\left.\left.\left.]_{\text {pre }}[\text { tangan }]_{\mathrm{N}}\right]-\mathrm{an}\right]_{\mathrm{suf}}\right]_{\mathrm{N}}\right]$

7.7 Confix pen-an (occurs: 2 times)

pen-an 1 DS : pencegahan "prevention" $(\mathrm{V} \rightarrow \mathrm{N})$ from cegah "preventive"

WFR :[[pen- $\left.\left.\left.\left.]_{\text {pre }}[\text { cegah }]_{\mathrm{V}}\right]-\mathrm{an}\right]_{\text {suf }}\right]_{\mathrm{N}}\right]$

pen-an 2 DS : pencalonan "nomination" $(\mathrm{N} \rightarrow \mathrm{N})$ from calon "candidate" 
WFR :[[pen- $\left.\left.\left.\left.]_{\text {pre }}[\text { calon }]_{\mathrm{N}}\right]-\mathrm{an}\right]_{\mathrm{suf}}\right]_{\mathrm{N}}\right]$

Table 1. Derivational affixes of Indonesian N-F

\begin{tabular}{|c|c|c|c|}
\hline No. & Type of Affixes & Occurance & Percentage \\
\hline 1. & Suffix -an & 9 times & $\frac{9}{47} \times 100 \%=19,1 \%$ \\
\hline 2. & Infix -em- + Suffix -an & 2 times & $\frac{2}{47} \times 100 \%=4,3 \%$ \\
\hline 3. & Infix -el- & Once & $\frac{1}{47} \times 100 \%=2,1 \%$ \\
\hline 4. & Confix per-an & 10 times & $\frac{10}{47} \times 100 \%=21,3 \%$ \\
\hline 5. & Confix ke-an & 22 times & $\frac{22}{47} \times 100 \%=46,8 \%$ \\
\hline 6. & Confix pe-an & Once & $\frac{1}{47} \times 100 \%=2,1 \%$ \\
\hline 7. & Confix pen-an & 2 times & $\frac{2}{47} \times 100 \%=4,3 \%$ \\
\hline Total & & 47 times & $=100 \%$ \\
\hline
\end{tabular}

\section{Findings}

Based on the analysis of data the findings indicated that there are 7 types of derivational affixes of Indonesian $\mathrm{N}-\mathrm{F}$ exists in newspaper editorial of kompas. The different types of the subject matter are (suffix -an, infix -em- + suffix -an, infix -el-, confix per-an, confix ke-an, confix pe-an and confix pen-an). This is to say that the diversity of the use of Indonesian language through mass-media is considered important in terms of some aspects in social context such as politic, culture as well as education.

\section{Discussion}

Referring to the types of derivational affixes of Indonesian N-F, there are some important aspects that the process of derivational affixes of Indonesian N-F very from one variation to another types informing N-F. This is the way of attaching any affixes to the base such as adjective forming noun, verb forming noun and noun forming noun. This phenomena takes an important role to be considered for the researcher to conduct another subject of the research on the use of language through mass-media especially for daily newspaper editorial kompas in Indonesia. Viewed from the linguistic points of view this research is concerned with the study of morphology in Indonesia and it will give some contribution to the world who are interested to conduct the research through any mass-media especially in the field of linguistics.

\section{Conclusion}

So far having disscussed and analysed the data the researcher would like to draw some conclusion as follows. There are some different types of derivational affixes of Indonesian N-F namely suffix -an, infix -em- + suffix -an, infix -el-, confix per-an, confix ke-an, confix pe-an and confix pen-an. This different types are the phenomena of 
the development of the use of Indonesian (bahasa Indonesia) today. In other word the function of Indonesian today developed much more diversity based on the social context. Such as politic, culture and education.

\section{Acknowledgement}

The researcher would like to express his gratitude to The State University of Medan (Unimed), North Sumatera, Indonesia for the publication of this article.

\section{References}

Allan, K. (2001). Natural Language Semantic. Massachusetts: Blackwell.

Aronoff, M., \& Fudeman K. (2005). What is Morphology? Australia: Blackwell.

Bauer, L. (1988). Introducing Linguistic Morphology. Edinburg University. Edinburg.

Chaer, A. (2008). Morfologi Bahasa Indonesia (Pendekatan Proses). Jakarta: Rineka Cipta.

Depdikbud. (1997). Kamus Besar Bahasa Indonesia. Jakarta: Balai Pustaka.

Echols, J. M., \& Shadily, H. (2003). Kamus Indonesia-Inggris. Jakarta: Gramedia Pustaka Utama.

Echols, J. M., \& Shadily, H. (2005). Kamus Inggris-Indonesia. Jakarta: Gramedia Pustaka Utama.

Haspelmath, M. (2002). Understanding Morphology. New York: Oxford University Press.

Katamba, F. (1994). Morphology. London: The Macmillan Press.

Kompas, 8 Maret 2016. Tajuk Rencana Kembali ke Ruang Batin. Halaman 6.

Kridalaksana, H. (1996). Pembentukan Kata dalam Bahasa Indonesia. Jakarta: Gramedia Pustaka Utama.

Nida, E. A. (1962). Morphology: The Descriptive Analysis of Words (2nd ed.). Canada: The University of Michigan Press.

Scalise, S. (1984). Generative Morphology. Dordrecht: Foris Publications.

Sibarani, R. (2006). An Introduction to Morphology. Medan: Poda.

Quinn, G. (2001). The Learner's Dictionary of Today's Indonesian. Sydney: Allen \& Unwin.

Zainuddin. (1986). A Contrastive Analysis of the English Sounds and Those of Indonesian. Unpublished. Sydney: The University of Sydney.

http://en.wikipedia.org/wiki/Indonesian.language (accessed on March 26, 2016).

\section{Copyrights}

Copyright for this article is retained by the author(s), with first publication rights granted to the journal.

This is an open-access article distributed under the terms and conditions of the Creative Commons Attribution license (http://creativecommons.org/licenses/by/3.0/). 